Arab Univ. J. Agric. Sci., Ain Shams Univ., Cairo, 14(1), 249-264, 2006

\title{
COMPARISON BIOCHEMICAL OF THE DESCENDANTS RESULTING FROM FIVE BACK CROSS-COUNTRY RACE GENERATIONS AND THEIR INHERITANCE OF DURUM WHEAT CROSSES
}

[16]

\author{
Barkat $^{1}$, M.
}

\begin{abstract}
This study was carried out to compare, on the basis of some biochemical nature, five generations of backcrossing resulting from six crosses between four varieties of durum wheat (M, W, S and P) as three crosses $\mathrm{MxW}, \mathrm{MxS}$, and $\mathrm{PxW}$ along with their reciprocals WxM, SxM, and WxP. A sufficient knowledge of the biochemical characteristics of the grain and their genetic transmissions, allows their use in selection. These characteristics can be used as criteria for selection of seeds for more judicious orientation. From the obtained results, a relative variability appeared at the various varieties and their descendants for the studied parameters (the weight of thousand grains, content of protein, moisture content, the volume of sedimentation and capacity of hydration of the gluten). Generally, the studied samples are relatively rich in proteins. The descendants of cross $\mathrm{MxW}$ have on average a significant volume of sedimentation, they can be used for wheat improving. For the moisture content, cross $\mathrm{MxW}$ records the greatest value with a more significant descendants BC5. With regard to the polymorphism of the glutenines, some bands were transmitted by the recurrent parent varieties used as female parents.
\end{abstract}

Keywords: Descendants back cross, Durum wheat, Grain protein, Grain biochemical characteristics and glutenines of wheat

\section{INTRODUCTION}

In Algeria, wheat and particularly the durum wheat constitute the principal cereal culture. Its production remains, however, irregular and weak to cover the request for the increasing human popula- tions. To face this situation, the country resorted to import, became excessively expensive with the passing of years.

The search for a genetic improvement of the varieties led many researchers to be interested in genetic variability by varietal creation and the selection of new pow-

1- Department of Nutrition and Agro-alimentary Technologies, Faculty of Science, University of Constantine, Algeria

(Received November 17, 2004)

(Accepted December 10, 2005) 
erful genotypes inside the hybrid varieties, having parameters of tolerance and adaptation to the environmental conditions. The selected seed is a source of increase in the quantitative and qualitative outputs when it is well used and remains the only powerful tool to improve our cultivation of cereals.

A study, ensuring a sufficient knowledge of the technological, physicochemical characteristics of the grain and their genetic transmissions, allows their use in selection. These characteristics can be used as criteria with an adequate selection of seeds for a more judicious orientation. The aim of this work is initially to create a new genetic material, characterizing on the basis of some possible physicochemical nature, the whole of the vegetable material available and finally to classify and to select descendants having the best performances than the parental varieties $(\mathrm{W}, \mathrm{M}, \mathrm{S}, \mathrm{P})$.

\section{MATERIEL AND METHODS}

For our wheat material, it was possible to specify some physicochemical parameters of orientation in the selection, in particular the content of protein (PG), moisture (MG), the weight of 1000 grains (WG), the sedimentation test (SDS) and the content of gluten in grains (GL). For the other physicochemical tests, it was difficult for us to use them because of the small quantities of available grains.

The choice of the four parents waha (W) , Mohamed ben bachir (M), polonicum (P) and sahel $77(\mathrm{~S})$ is based on one of these characteristics: technological properties represented by the force of the gluten and the grain content of proteins as well as test of sedimentation and the moisture content of grains.
The studied wheat material consists of the parental varieties and downward resulting from each of five back-cross generations $\left(\mathrm{BC}_{1}, \mathrm{BC}_{2}, \mathrm{BC}_{3}, \mathrm{BC}_{4}\right.$, and $\left.\mathrm{BC}_{5}\right)$, for the cross combinations: ( $\mathrm{WxP}, \mathrm{WxM}$ and $\mathrm{SxM}$ ) as well as their reciprocals (PxW, MxW and MxS). According to Itgc, (1979), the characteristics of the parental varieties are as follows:

- Waha (W): Variety of medium PMG, rather good semolina quality

- Sahel 77 (S): variety of high PMG.

- Polonicum (P): Variety of medium PMG, rather good quality.

- Mohamed Ben Bachir (M): variety of high PMG and good semolina quality.

\section{METHODS}

\section{Water content or moisture percentage (MG)}

The determination of the water content is carried out according to the method described by Afnor, (1986). It is the loss expressed as a percentage mass, undergone by the product after desiccation with drying oven $\left(130^{\circ} \mathrm{C}-133^{\circ} \mathrm{C}\right)$ during 2 hours on a test specimen of $5 \mathrm{G}$. The results are expressed as a percentage dry matters and are the average of tests.

\section{Content of proteins (PG)}

The determination of the content of total proteins is based on the proportioning of nitrogen according to the method of Kjeldahl described by Afnor, (1986). The multiplying coefficient 5.7 is used to pass from the mineral measurement of nitrogen with the content of proteins of the wheat grain. 


\section{0 grains weight (WG)}

The determination of the weight of 1000 grains is carried out according to the method described by standard Afnor, (1986). It is done by counting grains weighing 30 grams and estimated the average 1000 grain weight.

\section{Sedimentation test (SDS)}

The force of wheat flour can be measured according to the properties of swelling of proteins in medium based on lactic acid and of S.D.S. For that, $1 \mathrm{~g}$ of semolina is put in a graduated test-tube in contact of a lactic acid solution at $12.5 \%$ and S.D.S to $3 \%$. The swelling indeed represents the quantity of water absorptive by proteins. The strong wheat does not inflate whereas the weak wheat inflates until the complete disintegration of proteins.

The quantity of deposit makes possible to classify wheat according to their force. This index varies from 0 to 70 units (Selselet, 1991).

- Less than 18: insufficient wheat.

- 18 to 28: wheat of good pastry value.

- 28 to 38: wheat of very good pastry value.

- More than 38: strong wheat.

\section{Determination of the gluten}

The proportioning of the gluten rests on its insolubility in salted water and the property which it has to agglomerate when mixes in a water eliminates the other components. The plastic mass is weighed in a wet state then after desiccation (Kiger et Kiger, 1967).
The determination of the wet rate of gluten (GLW) and dry gluten (GLD) allows to estimate the capacity hydration of the gluten (HCG) which informs about \% of water contained as follows:

\section{Hydration capacity of gluten $\mathrm{HCG}=$ [GLW-GLD/GLW]. 100.}

The capacity of hydration for the normal gluten is approximately $66 \%$ and may increase to $69 \%$. The normal value of the dry gluten is about $12 \%$ where as the standard of the content of wet gluten is $27.85 \%$ (Calvel, 1984).

\section{Study of the polymorphism of subunits glutenins of high weight molecular and low-weight molecular (SG-HMW and SG-LMW).}

Only the six descendants resulting from the fifth generation of Back crosscountry race $(\mathrm{W} / 6 / \mathrm{P}, \mathrm{P} / 6 / \mathrm{W}, \mathrm{M} / 6 / \mathrm{W}$, $\mathrm{W} / 6 / \mathrm{M}, \mathrm{M} / 6 / \mathrm{S}$ and $\mathrm{S} / 6 / \mathrm{M}$ ) and the parental varieties (Sahel 77, Mohamed Ben Bachir, Waha and Polonicum) are studied.

The sequential extraction of the lowweight glutenins molecular (SG-LMW) and of high molecular weight (SG-HMW) were carried out according to the method of Singh et al (1991). This method describes a procedure simplified for the separation of the sub-units glutenins. It allows a better resolution of glutenins HMW and LMW and was tested on a great number of varieties of durum wheat. The complex SDS-polypeptide is the polypeptide of the densities of loads primarily identical and (in theory) migrate in the polyacrylamide gels only according to their molecular size (Autran, 1987). 


\section{RESULTS AND DISCUSSION}

The statistical analysis of the data calculated between the values of descent BC5 and their parents carried out on the six crossings revealed a structuring variability. This variability is structured much better by certain variables than by others for the unit of the various crossings carried out. The evaluation of the descendants of each generation resulting from a back cross-country race led to observe more or less significant differences according to the crossing considered. The standard deviation, the heritability in the broad sense and the coefficient of variation are more or less significant between the various descents for certain crossings than for others.

\section{Moisture percentages in grains}

A variability is observed for moisture between the various crossings carried out, the standard deviation and the coefficient of variation are very significant at crossing $\mathrm{WxP}$ and are worth 0.374 and 7.586 respectively. One can classify the various crossings according to their average values as follows: $\mathrm{MxW}>\mathrm{SxM}>\mathrm{MxS}>$ $\mathrm{WxM}>\mathrm{WxP}>\mathrm{PxW}$ (T.1). On the average, for the whole of the studied crossings, crossing M/W seems to be most interesting, where we note that the highest value is that of descent BC5 (11.88) followed descent BC3 (11.82). The lowest moisture content is observed at descent BC4 (10.99). We also notice that this value is higher than that of the average starting relative $[(\mathrm{M}+\mathrm{W}) / 2](10.4)$ and also to the values of its two parents: female $\mathrm{W}(10.30)$ and male $\mathrm{M}(10.50)$.

With regard to the values of heritability in the broad sense, no cross shows significant values (T.1).
The coefficient of regression varies from -0.620 at crossing $\mathrm{S} / \mathrm{M}$ to 0.402 at $\mathrm{MxW}$. As for the response to the selection, it is variable and it seems effective for all the crosses except crosses SxM and $\mathrm{MxS}$ (T.1). On one hand, the best aptitude specific to the combination, for moisture, is noted at the $\mathrm{MxW}$ (13.47) on the other hand the weakest is that of SxM (12.99) (T.1). The results of the water content of the sample indicate that the values vary from 11.00 for PxW to 11.24 for $\mathrm{M} / \mathrm{W}$, they are thus regarded as weak compared to the standard (12 to $14 \%$ ) (Afnor, 1986), but they are close to those of Calvel, (1984) who reported a range from 10 to $12 \%$. Actually the water content is not a varietal factor, its fluctuations are due especially to the climatic conditions (Godon, 1991). Indeed, the period from 1997 to 2002 is characterized by a considerable hydrous deficit which influenced the vegetative stage of wheat.

With the scale of the generation, the best response to selection is recorded for descendants $\mathrm{BC} 1$ of the cross W/M (1.82) (T.2). The whole of the grains of the descendants and the parents is regarded as a whole of dry grains favourable to the conservation.

\section{Grain content of protein}

On one hand, with regard to the grain content of protein, the classification of the crosses in ascending order is as follows: MxW, MxS, PxW, WxM SxM and $\mathrm{WxP}$ follows. The standard deviation is very significant for cross $\mathrm{PxW}$ (1.104), on the other hand the most significant coefficient of variation is observed for cross WxP (18.44) (T.3). For cross MxW, the most significant descent is $\mathrm{BC} 3$ (15.75), the low value is noted at descent 
Table 1. Grain moisture (MG): Mean \pm standard deviation (Mean. \pm S.d.) coefficient of variation (C.V), heritability in the broad sense $\left(\mathrm{H}^{2}\right.$, coefficient of regression (R), response to the selection (Rs) and aptitude specific to combination (ASC)

\begin{tabular}{|ccccccc|}
\hline generation & Mean. \pm S.d & $C . V$. & $H^{2}$ & $r$ & $R s$ & $A S C$ \\
\hline$M / W$ & $11.24 \pm 0.36$ & 7.162 & 0.468 & 0.402 & 2.28 & 13.47 \\
$W / M$ & $11.04 \pm 0.34$ & 6.925 & 0.416 & 0.305 & 2.19 & 13.22 \\
$P / W$ & $11.00 \pm 0.27$ & 5.455 & 0.413 & -0.04 & 1.76 & 13.24 \\
$W / P$ & $11.02 \pm 0.37$ & 7.586 & 0.413 & 1.082 & 2.68 & 13.17 \\
$S / M$ & $11.18 \pm 0.25$ & 4.952 & 0.194 & -0.62 & -0.09 & 12.99 \\
$M / S$ & $11.70 \pm 0.16$ & 3.169 & 0.367 & -0.04 & -0.09 & 13.03 \\
\hline
\end{tabular}

Table 2. Grain moisture (MG): Response to the selection measured with each generation of the six crosses

\begin{tabular}{|lcccccc|}
\hline generation & $W / M$ & $M / W$ & $W / P$ & $P / W$ & $M / S$ & $S / M$ \\
\hline$F 1 / B C 1$ & 1.82 & 1.43 & 1.06 & 1.63 & 08 & 0.7 \\
$B C 1 / B C 2$ & 0.41 & 0.78 & 0.65 & 1.04 & 0.89 & 0.58 \\
$B C 2 / B C 3$ & -0.25 & 1.14 & 0.08 & 0.13 & -0.89 & -0.56 \\
$B C 3 / B C 4$ & 0.55 & -0.26 & 0.59 & 0.39 & 0.78 & 0.81 \\
$B C 4 / B C 5$ & 1.14 & 1.18 & 0.71 & 1.32 & 0.75 & 0.1 \\
\hline
\end{tabular}

Table 3. Grain content of proteins (PG): Mean \pm standard deviation (Mean. \pm S.d.) coefficient of variation $(\mathrm{C} . \mathrm{V})$, heritability in the broad sense $\left(\mathrm{H}^{2}\right.$, coefficient of regression $(\mathrm{R})$, response to the selection $(\mathrm{Rs})$ and aptitude specific to combination (ASC)

\begin{tabular}{|lllllll|}
\hline generation & Mean. \pm S.d & C.V. & \multicolumn{1}{c}{$H^{2}$} & \multicolumn{1}{c}{$r$} & $R s$ & ASC \\
\hline$M / W$ & $14.26 \pm 0.98$ & 15.33 & 0.270 & $0.837 * *$ & -6.90 & 15.47 \\
$W / M$ & $13.56 \pm 1.03$ & 17.56 & $0.747 *$ & $0.919 * *$ & -6.53 & 14.63 \\
$P / W$ & $14.11 \pm 1.10$ & 17.49 & $0.520^{*}$ & 0.299 & -7.67 & 15.16 \\
$W / P$ & $13.22 \pm 1.09$ & 18.44 & $0.657 *$ & 0.313 & -6.80 & 14.24 \\
$S / M$ & $13.25 \pm 1.04$ & 17.60 & $0.580^{*}$ & $0.600^{*}$ & -5.99 & 14.27 \\
$M / S$ & $14.12 \pm 1.09$ & 17.07 & 0.277 & 0.497 & -7.07 & 12.74 \\
\hline
\end{tabular}

$*$, ** significant with $5 \%$ and $1 \%$ respectively 
resulting $\mathrm{BC} 2$ (12.83). We also notice that this value is lower than the relative average starting $[(\mathrm{P}+\mathrm{W}) / 2](16.45)$ and also than the values of its two parents: female $\mathrm{M}(21.40)$ and male $\mathrm{W}(15.10)$.

As for the habitability in the broad sense, significant values are observed for crosses WxM, PxW, WxP and SxM (T.3). According to Nachit and Ketata (1991), this parameter seems to be influenced by the medium or the genotype interactions with medium and that in irrigated conditions, moderate average values of heritability in the broad sense were recorded for this parameter. Branlard $\boldsymbol{e t}$ al (1991) indicated that the low value of heritability of this criterion results from a genetic determinism complexes (polygenic character) and of a significant influence of the agronomic and environmental conditions on the expression of this character.

The coefficient of regression varies from 0.299 for cross PxW to 0.837 for $\mathrm{MxW}$. With regard to the response to selection, it is variable and it does not seem to be effective for any cross (T.3). The strongest value of aptitude specific to the combination, for the grain content of protein, is observed for the weakest $\mathrm{MxW}$ and also is observed for SxM (T.3).

With the scale of the generation, the best response to the selection is recorded at descendants $\mathrm{BC} 2$ of the cross $\mathrm{WxM}$ (14.73) (T.4).

Generally, the values of the protein content in grains vary on the average from 13.22 for $\mathrm{WxP}$ to 14.26 for $\mathrm{MxW}$. They are very suitable compared to the standard (8 to 16) (Boudreau, 1992), but higher than that quoted by Bar, (1995) (11 to $14 \%)$.

According to Selselet, (1991), the content of protein is a significant parame- ter of quality. The variations of the grain content of protein can be due to many factors such as the variety, the stage of maturity, the environment, the fertilization and heredity (Godon, 1991; Nachit and Ketata , 1991).

Leclerck, (1977) reported that the climatic conditions have much more influence than the seed or the ground and that the content of protein is a function of the locality. Later, work of certain authors particular those of Namoune, (1989) arrived to the same conclusions and as showed as the high temperatures increase the content of protein in wheat grains.

Periods of significant rains decrease the contents of proteins but the dry seasons raise them (Hlynka, 1964).

Leclerck, (1977) observed that the nitrate amount at the maturation stage of the grain increases the content of protein.

In the same way, Hlynka (1964), stated that a nitrogenized manure increases the content of protein. Generally, all the descendants and their parents are very rich in protein. According to Kaan et al (1995), content of high protein of the grain is a genetic character of cardinal importance for obtaining products of quality.

\section{Test SDS of sedimentation}

The comparison of the average of the various crosses shows, by ascending order, the following classification: $\mathrm{MxW}$, PxW, WxP, SxM, WxM and MxS. The standard deviation and the coefficient of variation are very significant for cross $\mathrm{WxP}$ and are worth 1.95 and 17.54 respectively (T.5). In addition, analysis of variance showed a highly significant difference between the descendants of the cross MxW. 
For cross $\mathrm{MxW}$, the most significant descent is that of the $\mathrm{BC} 1$ (29.25), weakest is noted at the descent resulting from the BC2 (21.5). We also noticed that this value is higher than that of the average relative starting $[(\mathrm{M}+\mathrm{W}) / 2]$ (28.5) and also to those two parents: females M (33.00) and male W (24.00).

The heritability in the broad sense was most significant for cross WxP. The coefficient of regression ( $\mathrm{R})$ varies from0.536 for cross $\mathrm{MxW}$ to 1.344 for $\mathrm{MxS}$. As for the response to the selection, it is also very variable and it seems to be effective for all crosses except for PxW (T.5).

The strongest value of specific aptitude to the combination, for the volume of sedimentation, is recorded for the weakest cross $\mathrm{MxW}$ followed by the cross PxW (T.5).

With the scale of the generations, the best response to the selection is observed for descendants BC5 of the cross $\mathrm{MxS}$ (T.6).

Volumes of sedimentations vary on average from 23.01 for $\mathrm{PxW}$ to $25.82 \mathrm{ml}$ at MxW. These values show that the studied varieties and descendants are generally in the standard of wheats of good pastry value (18 and $38 \mathrm{ml}$ ) (Rousset et Loisel, 1984). The variations of volume of sedimentation due to the influence of the content of protein and the strength baker (Branlard and Autran, 1987) are quoted by (Benarioua, 2001).

\section{Determination of the grain gluten (wet and dry gluten)}

The capacity of hydration of the gluten calculated between the values of descent BC5 and their parents allowed us to establish the classification of the crosses by ascending order, according to: $\mathrm{PxW}$, MxW, WxP, WxM, SxM and MxS. The standard deviation and the coefficient of variation are very significant at cross PxW and are worth 2.87 and 9.57 respectively (T.7).

Cross PxW has the best capacity of hydration, the most interesting descent is that of the BC3 (79.96). We also notice that this value is higher than that of the average starting relative $[(\mathrm{P}+\mathrm{W}) / 2]$ (66.09) and also the two parents: females $\mathrm{P}$ (67.11) and male W (65.08).

As for habitability in the broad sense, the actual values for all the crosses are significant except for crosses PxW and $\mathrm{MxS}$ (T.7). The coefficient of regression varies from -0.609 for cross PxW to 1.20 for SxM. For the response to the selection, it seems to be effective only for crossing MxS (T.7). The best specific aptitude to the combination, for the capacity of hydration, is noted for the weakest $\mathrm{P} / \mathrm{W}$ and is observed at $\mathrm{SxM}$ (T.7). With the scale of the generations, the best response to selection is recorded for the descendant $\mathrm{BC} 3$ of the cross PxW (T.8).

With regard to the capacity of hydration, the statistical analysis indicates that the values vary from 61.28 at $\mathrm{M} / \mathrm{S}$ and 67.10 at $\mathrm{P} / \mathrm{W}$. According to Kaan et al (1995), the capacity of hydration for the normal gluten is $66 \%$ of dry matter.

\section{Correlations between the studied char- acteristics}

The examination of the matrix of correlation (T.9) as well as the test of significance of the correlations enabled us to reveal correlations between various parameters. According to the matrix of correlations between the studied parameters, 
Table 4. Grain content of proteins (PG): Response to the selection measured with each generation of the six crossings

\begin{tabular}{|lllllll|}
\hline \multicolumn{1}{c}{ generation } & $W / M$ & $M / W$ & $W / P$ & $P / W$ & $M / S$ & $S / M$ \\
\hline$F 1 / B C 1$ & 14.47 & 12.46 & 11.71 & -4.74 & -6.67 & -6.74 \\
$B C 1 / B C 2$ & 14.73 & 13.55 & 12.35 & 0.87 & -2.11 & 0.41 \\
$B C 2 / B C 3$ & 13.01 & -2.4 & -1.74 & -3.0 & -6.16 & -2.51 \\
$B C 3 / B C 4$ & 13.05 & -0.74 & -0.66 & -2.07 & -3.79 & -1.2 \\
$B C 4 / B C 5$ & 11.7 & -1.86 & -2.19 & -3.77 & -5.37 & -2.47 \\
\hline
\end{tabular}

Table 5. Volume of sedimentation (SDS): Mean \pm standard deviation (Mean. \pm S.d) coefficient of variation $(\mathrm{C} . \mathrm{V})$, heritability in the broad sense $\left(\mathrm{H}^{2}\right.$, coefficient of regression $(\mathrm{R})$, response to the selection $(\mathrm{Rs})$ and aptitude specific to combination (ASC)

\begin{tabular}{|lcccccc|}
\hline generation & Mean. \pm E.T & C.V. & $\mathrm{H}^{2}$ & $\mathrm{r}$ & $\mathrm{Rs}$ & ASC \\
\hline$M / W$ & $25.82 \pm 1.25$ & 10.85 & 0.254 & $-0.536^{*}$ & 2.82 & 30.19 \\
$W / M$ & $23.68 \pm 1.14$ & 10.80 & 0.448 & -0.051 & 2.01 & 27.63 \\
$P / W$ & $25.31 \pm 1.49$ & 13.23 & 0.414 & -0.251 & -4.23 & 24.20 \\
$W / P$ & $24.91 \pm 1.95$ & 17.54 & $0.850^{* *}$ & $0.508^{*}$ & 2.01 & 28.11 \\
$S / M$ & $24.16 \pm 1.11$ & 10.30 & 0.309 & -0.458 & 5.38 & 27.20 \\
$M / S$ & $23.01 \pm 1.05$ & 10.21 & 0.383 & 1.344 & 7.49 & 27.67 \\
* ** significant with 5\% and 1\% respectively & & &
\end{tabular}

Table 6. Volume of sedimentation (SDS): Response to the selection measured with each generation of the six crossings

\begin{tabular}{|lllllll|}
\hline \multicolumn{1}{|c}{ generation } & $W / M$ & $M / W$ & $W / P$ & $P / W$ & $M / S$ & $S / M$ \\
\hline$F 1 / B C 1$ & 2.53 & 3.87 & 65.8 & 68.23 & -10.08 & -3.2 \\
$B C 1 / B C 2$ & 0.82 & -0.33 & 66.85 & 65.43 & -6.15 & -1.82 \\
$B C 2 / B C 3$ & -7.55 & -9.57 & 59.82 & 79.96 & 3.16 & -8.06 \\
$B C 3 / B C 4$ & -0.93 & -3.8 & 60.2 & 60.91 & -2.99 & -3.5 \\
$B C 4 / B C 5$ & -3.42 & -4.35 & 62.1 & 60.79 & -1.84 & -2.01 \\
\hline
\end{tabular}


Table 7. Capacity of hydration of the gluten (HCG): Average \pm standard deviation (Mean. \pm S.d.) coefficient of variation $(\mathrm{C} . \mathrm{V})$, heritability in the broad sense $\left(\mathrm{H}^{2}\right.$, coefficient of regression $(\mathrm{R})$, response to the selection (Rs) and aptitude specific to combination (ASC)

\begin{tabular}{|ccccccc|}
\hline generation & Mean. \pm S.d & C. $V$. & \multicolumn{1}{c}{$H^{2}$} & \multicolumn{1}{c}{$r$} & \multicolumn{1}{c}{$R s$} & ASC \\
\hline$M / W$ & $64.51 \pm 02.08$ & 07.22 & $0.60^{*}$ & 1.031 & -5.49 & 74.89 \\
$W / M$ & $63.38 \pm 01.68$ & 05.94 & $0.66^{*}$ & $0.998^{* *}$ & -6.2 & 73.52 \\
$P / W$ & $67.10 \pm 02.87$ & 09.57 & 0.39 & -0.609 & -6.54 & 77.83 \\
$W / P$ & $63.53 \pm 01.30$ & 04.60 & $0.68^{*}$ & 1.010 & -4.32 & 73.72 \\
$S / M$ & $63.02 \pm 01.52$ & 05.41 & $0.61^{*}$ & 1.200 & -6.5 & 72.56 \\
$M / S$ & $61.28 \pm 01.81$ & 06.62 & 0.44 & 0.431 & 1.95 & 76.28 \\
\hline
\end{tabular}

$*$, ** significant to $5 \%$ and $1 \%$ respectively

Table 8. Capacity of hydration of the gluten (HCG): Response to the selection measured with each generation of the six crossings

\begin{tabular}{|lllllll|}
\hline \multicolumn{1}{|c}{ generation } & $W / M$ & $M / W$ & $W / P$ & $P / W$ & $M / S$ & $S / M$ \\
\hline$F 1 / B C 1$ & -3 & 0.75 & 6 & 1.35 & -7 & 0 \\
$B C 1 / B C 2$ & 4.75 & -9.62 & -5.75 & -6 & -2 & 6 \\
$B C 2 / B C 3$ & -1.74 & -2.9 & 3.37 & 4.26 & -4.55 & -0.47 \\
$B C 3 / B C 4$ & -3.97 & 0.35 & 4.23 & 0.88 & -3.65 & 0 \\
$B C 4 / B C 5$ & 1.01 & -4.19 & 3.9 & 2.21 & 25.38 & 5.28 \\
\hline
\end{tabular}

Table 9. Correlations between the studied tests

\begin{tabular}{|lccccccc|}
\hline & $M G$ & $P G$ & $S D S$ & $W G$ & $G L W$ & $G L D$ & $H C G$ \\
\hline$M G$ & 1.00 & & & & & & \\
$P G$ & $-0.588^{*}$ & 1.00 & & & & & \\
$S D S$ & -0.156 & 0.110 & 1.00 & & & & \\
$W G$ & 0.034 & 0.018 & 0.088 & 1.00 & & & \\
$G L W$ & -0.276 & 0.099 & 0.014 & $-0.506^{*}$ & 1.00 & & \\
$G L W$ & -0.056 & $-0.369 *$ & -0.030 & -0.258 & $0.388^{*}$ & 1.00 & \\
$H C G$ & -0.191 & $0.314^{*}$ & 0.059 & -0.014 & 0.242 & $-0.514^{*}$ & 1.00 \\
\hline
\end{tabular}

$*, * *$ significant at $5 \%$ and $1 \%$ respectively 
we note that there is no significant correlation between the moisture and the weight of thousand grains. As opposite to what we found in the literature that both tests are dependent one on the other; this result seems to be erroneous. According to Selselet, (1991), the variation of the weight of thousand grains can be an expression of the degree of scalding of physiological or pathological origin.

Abecassis, (1996) regards the weight of 1000 grains (WG) as a varietal criterion which can undergo fluctuations related in particular to empty seems. No significant correlation was noted between grain content of protein and the sedimentation test SDS. According to the bibliography, a highly significant correlation between them was already noted by Liu et al (1995). However, Kaan et al (1995) indicated that the volume of sedimentation can depend on the content of protein.

A positive correlation is slightly significant $(\mathrm{R}=0,388)$ between the wet gluten (GLW) and the dry gluten (GLD) which indicates that there is no strong variation related to the genotype concerning the aptitude of the gluten to be hydrated. According to Kaan et al (1995), the capacity of high hydration of the gluten would be due to an absorption of water in relation to its quality. More the gluten is of good quality, more it absorbs water and the larger difference between dry and wet gluten is expected. According to Cheriet, (2000), the capacity of hydration of the gluten (HCG) is due to the quality of wheat and its state of maturation.

A negative correlation is slightly significant $(\mathrm{R}=-0,369)$ between grain proteins content and the dry gluten. According to the bibliography, our results are not appropriate with those described in biochemistry where the gluten is regarded as a complex protein (glutenin and gliadin). The majority of the specialists recognize that the glutenins account on average $40 \%$ of proteins of the wheat flour (Dacosta, 1986).

A significant and negative correlation is recorded between grain moisture (MG) and the content of proteins (PG). Knowing that the content of proteins in the grain is highly dependent on the medium and the climate lasting the critical phases of development of the plant, this correlation is probably explained by the hydrous deficit which prevailed on the area of culture lasting the previous years. According to Cherdouh (1999), there is not any correlation between these two parameters. No significant correlation was observed between the content of gluten and the result of test SDS of sedimentation, this observation joins that of Dexter et al (1981).

\section{Study of the diversity of the glutenins of high molecular weight and low- molecular weight}

The subunits of high molecular weight were analyzed on 10 genotypes. Their mobilities were defined according to the nomenclature described by Payne et al (1984) and supplemented by Branlard et al (1991).

The analysis of the electrophoretic diagrams of the 4 parental varieties of durum wheat and 6 descendants resulting from the fifth generation of the back cross-country race made it possible to distinguish 6 types (Fig.1). The diversity 
Figure 1. Diagrams of the sub-units glutenins of high (SG-HMW) molecular weight and low molecular weight (SG-LMW)

of the electrophoretic bands of the SGHMW is rather significant (6/10).

- The first type gathers the variety Mohamed Ben Bachir and its descendants MxW and MxS having band 20.

- The second type is represented by descendant WxM having the band 6-8.

- The third type gathers the Waha variety and its descendant W/P having band 7.

- The fourth type is represented by descendant PxW having the band 6-8.

- The fifth type is represented by the Polonicum variety having band 20 .
- The sixth type gathers the Sahel variety and its descendant $\mathrm{S} / \mathrm{M}$ having the bands 6-8.

The descendants of the fifth generation of the back cross-country race $\mathrm{MxS}$ and $\mathrm{MxW}$ represent bands electrophoretic similar to those their parents female starting $\mathrm{M}$, in the same way for descendant $\mathrm{WxP}$ and his/her relative female starting $\mathrm{W}$, which means that these bands were transmitted by the recurring varieties used like parents females. The descendants of the fifth generation of the back crosscountry race $\mathrm{W} / \mathrm{M}$ and $\mathrm{SxM}$ has bands different from those of the male starting M. relative. 
The SG-HPM revealed in SDS-PAGE are already known, described and studied by Khelifi et al (1992), Benarioua (2001). The results concerning the parental varieties noted are roughly similar to those announced by Khelifi et al (1992), Cherdouh, (1999) and Benarioua, (2001).

The low-weight molecular gluténins form three groups of different mobilities (slow, intermediate and fast). The slow bands correspond to the SG-HPM (zone A) while the intermediate and fast bands correspond to the SG-FPM (zones B, C and D) (Jackson et al 1983).

The diversity of the electrophoretic bands of the SG-FPM also enabled us to distinguish 6 types of diagrams:

- The first type gathers the variety Mohamed Ben Bachir and its descendants $\mathrm{MxW}$ and $\mathrm{M} / \mathrm{S}$ having bands 2-4-6-1115 and 19.

- The second type is represented by descendant WxM

- The third type gathers the Waha variety and its descendant $\mathrm{WxP}$ having bands 5-8-9-12-13 and 16.

- The fourth type is represented by descendant PxW.

- The fifth type is represented by the Polonicum variety having bands 2-4-6-15 and 19.

- The sixth type gathers the Sahel variety and its descendant SxM.

Many studies showed that they are the glutenins LMW which are responsible for the quality of durum wheat (Payne $\boldsymbol{e t}$ al 1984; Pogna et al 1990; Ruiz and Carrillo, 1995).

\section{CONCLUSION}

A relative variability appeared at the various varieties and descendants for the studied parameters (the weight of thou- sand grains, content of protein, moisture content, the volume of sedimentation and capacity of hydration of the gluten).

All the descendants present on normal average of moisture content. For crossing $\mathrm{M} / \mathrm{W}$, we note an improvement of the content of proteins, volume of sedimentation and rate of moisture compared to the average parents and sometime compared to the parental varieties.

Generally, the studied samples are relatively rich in proteins. These results join those described by Cheftel et al (1985) where the content of protein is a transmissible factor but with variations related to heredity which are worth only $5 \%$.

The descendants of cross $\mathrm{MxW}$ have on average, a significant volume of sedimentation, they can be used like improving.

For the moisture content, the results obtained indicate that the various crosses are very close and are in the standards. Cross $\mathrm{MxW}$ records the greatest value whose most significant descent is the $\mathrm{BC} 5$, presenting a heritability in the broad sense significant, a response to the effective selection and a better aptitude for the combination. Many studies showed the genetic existence on the one hand in the variation of the water content although Doekes and Belderok (1976) consider that its variation would be rather environmental than genetic. In the other hand, Kuspira and Unrau (1957) found coherent results from one year to another, without interaction genotype $\mathrm{X}$ year (quoted by Felix, 1996)

The results obtained, for the content of proteins, indicate that the best crossing is $\mathrm{MxW}$ whose most interesting descent is the $\mathrm{BC} 3$, but presenting a heritability in the broad sense non significant, 
this one could be due to significant phenotypical effects and genotypic weak and a better aptitude for the combination. In the same way, this crossing presents a significant coefficient of regression of downward. It seems to be also interesting for the volume of sedimentation with a very low coefficient of regression, this is due probably to the weak environmental effects.

With regard to the polymorphism of the glutenins, the descendants of the fifth generation of the back cross-country race $\mathrm{MxS}$ and MxW represent bands electrophoretic similar to those parents female starting $\mathrm{M}$, in the same way for descendant $\mathrm{WxP}$ and his/her relative female starting $\mathrm{W}$, which means that these bands were transmitted by the recurring varieties used like parents females. The descendants of the fifth generation of the back cross-country race $\mathrm{WxM}$ and SxM has similar bands of those of the male starting $\mathrm{M}$ relative.

\section{REFERENCES}

Abecassis, J. (1996). Comprendre la qualité : la valeur semoulière comment s'explique t'elle ? Coll. Perspectives blé dur. INRA. Montpellier. France. pp. 3756.

Afnor, (1986). Céréales et Produits Céréaliers. $3^{\text {ème }}$ Ed. pp. 34-44. Recueil des normes françaises. Association Française de Normalisation, Cedex,.Paris.

Autran, J.C. (1987). Cours d'électrophorèse. pp. 13-29. Université des Sciences et Techniques du Languedoc, France.

Bar, C. (1995). Contrôle de la Qualité des Céréales et Protéagineux. 253 pp. Guide Pratique Ed. Itcf Paris.
Benarioua, S. (2001). Utilisation des Marqueurs Biochimiques dans l'Amélioration Génétique de la Qualité des Blés. pp. 61-73. Thèse de Magister, I.S.N, Université Mentouri. Constantine. Algérie..

Boudreau, A. (1992). Le Grain de Blé. pp. 25-49 In: le Blé - Eléments Fondamentaux et Transformation. Ed. Les Presses de l'Université Laval. Paris.

Branlard G. and J.C. Autran (1987). Comparaison of 456 technological parameters used in breeding for bread wheat quality evolution. J. Genet. and Breed. 45: 263-280.

Branlard, G.; M. Rousset; W. Loisel and J.C. Autran (1991). Comparaison of 456 technological parameters used in breeding for bread wheat quality evolution. J. Genet. and Breed. 45: 263-280.

Calvel, R. (1984). La Boulangerie Moderne, 459 pp. Ed.: Eyrolles, Paris.

Cheftel, J.C.; L. Cuq et D. Lorient (1985). Protéines Alimentaires. 309 pp. Ed. Technique et Documentation. Lavoisier, Paris.

Cherdouh, A. (1999). Caractéristique Biochimique et Génétique des Protéines de Réserve des Blés Durs Algériens (Triticum durum Desf). Relation avec la Qualité. pp.77-86. Thèse Magister, I.S.N, Université Mentouri. Constantine. Algérie..

Cheriet, G. (2000). Etude de la Galette : Différents Types, Recettes et Modes de Préparation. pp. 56-75. Thèse Magister. I.N.A.T.A.A. Université Mentouri. Constantine. Algérie.

Dacosta, Y. (1986). Le Gluten de Blé et ses Applications. 129pp. Ed. Apria.

France

Dexter, J.E.; R.R. Matsuo; K.R. Preston and R.H. Kilborn (1981). Comparison of Gluten Strenght, mixing proper- 
ties, baking quality and spagetti quality of some Canadian durum and common wheats. Can. Int. Food. Sci. Technol. J. 14(2):108-111.

Doekes, G.J. and B. Belderok (1976). Kernel hardness and baking quality of wheat. Genetic analysis using chromosome substitution lines. Euphitica 25: 565-576

Felix, I. (1996). Etude de la Diversité Allélique des Protéines de Réserve (Gluténines et Gliadines), en relation avec des tests de technologies appréciant la valeur d'utilisation du blé tendre (Triticum aestivum L.). INRA -Clermont-Ferrand. pp. 18-28.

Godon, B. (1991). Les constituants des céréales: nature, propriétés et teneurs. pp. 1-19. In: Biotransformation des Produits Céréaliers. Ed. Technique et Documentation. Lavoisier. Paris.

Hlynka, L. (1964). Influence of temperature, speed of mixing and salt on some reological proprieties of drought in farinograph . Cereal. 39: 286-303.

Itgc, (1979). Le Laboratoire des Technologies des Céréales de l'ITGC. Céréaliculture 10: 19-24. Revue Scientifique et Technique d' El Harrach. Alger, Algérie.

Jackson, E.A.; L.M. Holt and P.I. Payne (1983). Caracterisation of high molecular weight gliadin and low molecular weight glutenin subunits of wheat endosperm by two dimensional electrophoresi and the chromosomal localization of their controlling genes. Theor. App. Genet. 66: 29-37.

Kaan, F.; B. Chihab; C. Borles; P. Monneveux and G. Branlard (1995). Pré amélioration et Amélioration du Germoplasme de Blé dur pour les Produits de Qualité. In: Option Méditerranéenne, 271 pp. Série A : Séminaire de
Blé Dur dans la Région Méditerranéenne. No. 22 Diponzo N., F.Kaan, M. Nachit., Ed. Ciheam. Espagne. 17-19 Novembre 1993.

Kiger J.L. and J.G. Kiger (1967). Techniques Modernes de la Biscuiterie, Pâtisserie, Boulangerie Industrielles et Artisanales et des Produits de Régime. 676 pp. Ed. Tech. et Doc. Lavoisier, Paris.

Khelifi, D.; G. Branlard and M. Bourgeon Greneche (1992). Diversity of some D zone W-gliadin of bread wheat as revealed by two step A-PAGEISDS PAGE technique. J. Genet. Breed 46: 351-358

Kuspira, J. and J. Unrau (1957). Genetic analysis of certain characters in common wheat using whole chromosome substitution lines. Can. J. Plant. Sci. 37: 300-326.

Leclerck, J. (1977). L'aspect variétal de la qualité technologique des blés tenders. U.A. No. 391, 5, (77): 33-37.

Liu, C.Y.; A.J. Rathjen; K.W. Shepherd; P.W. Gras and L.C. Giles (1995). Grain quality and yield characteristics of D genome disomic substitution lines in Langdon (Triticum turgidum var durum). Plant Breed. 114: 34-39.

Namoune, H. (1989). Détermination des Aptitudes Technologiques des Principales Variétés de Blé Tendre Cultivées en Algérie. pp. 16-32. Thèse de Magister. INATAA. Université de Constantine. Algérie.

Nachit, M.M. and H. Ketata (1991). Selection of lmorpho-physiological traits for multiple abiotic stresses resistance in durum wheat (Triticum durum L. var. Durum). In: Physiology- breeding of winter cereal for stressed mediterranean environments. Acevedo E.; A.P. Conesa; P. 
Monneveux; J.P. Srivastava (Ed.). Colloques de l'INRA 55: 391-400.

Payne, P.L.; L.M. Holt; A. Jakson and C.N. Law (1984). Wheat storage proteins: their genetic and their potential for manipulation by plant breeding. Phil. Trans. R. Soc. Lond. 304: 359-371.

Pogna, N.E.; J.C. Autran; G. Mellini; D. Lafiandra and P. Feillet (1990). Chromosome 1B encorded gliadins and glutenins subunits in durum wheat: genetics and relationschip to gluten strength. $\boldsymbol{J}$. Cereal. Sci. 11: 15-34.

Rousset M. and W. Loisel (1984). Tests de Laboratoire. pp. 467-509. In: Guide Pratique d'Analyse dans les Industries des Céréales. Godon, B. et W. Loisel,
Ed. Technique et Documentation. Lavoisier. Apria. France.

Ruiz, M. and J.M. Carrilo (1995). Relationschip between prolamins proteins and some quality parametrers in durum wheat. Plant. Breed. 114: 40-44.

Selselet Attou, G. (1991). Technologie des Céréales et Produits Dérivés. 147 pp. Document à l'Usage des Etudiants. Option: Technologie Agro-alimentaire. Office des Publications de I' Institut Agronomique, Mostaganem, Alge'rie. Singh, N.K.; K.W. Shepherd and G.B. Cornish (1991). A simplified SDS PAGE procedure for separating LMW subunit glutenin. J. Cereal Sci. 14: 203-208. 


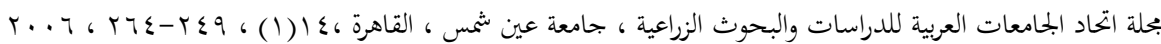

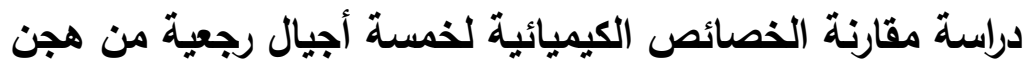
القمح الأكر ونظام توريثها

\section{مليكة بركات'}

1- قسم التظذية والتكنولوجيا الززاعية - كلية العلوم - جامعة قسنطينة - الجزائر

استخدم في هدا البحث أربعة أصناف نسبة و جودة الجلو تين بالحبوب على أساس

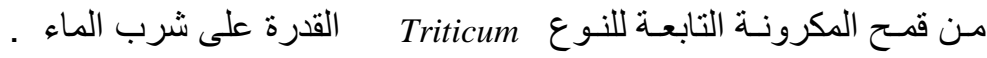

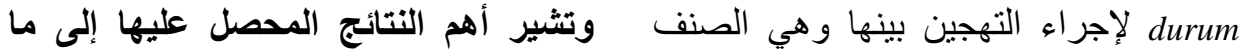

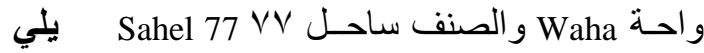

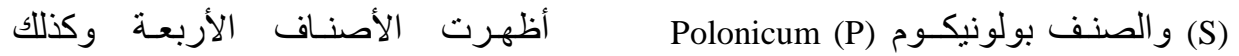

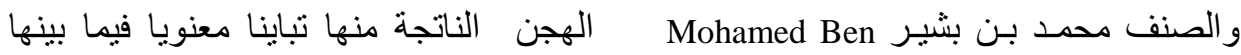

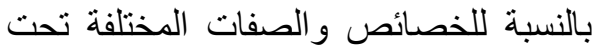
. Bachir (M)

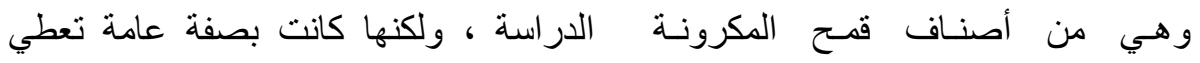

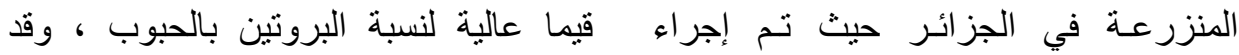

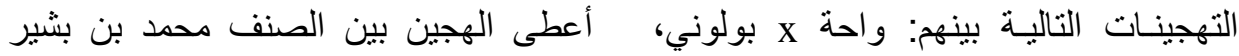

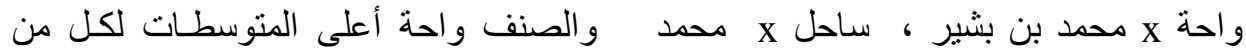

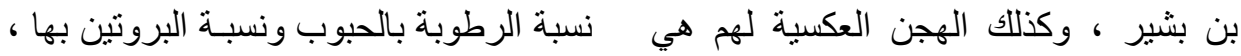

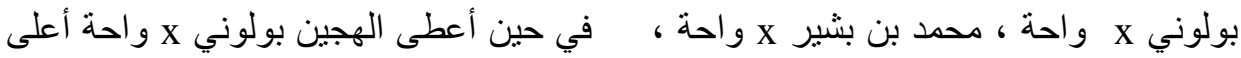

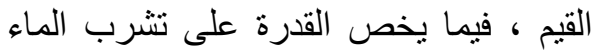

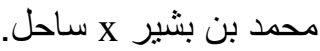

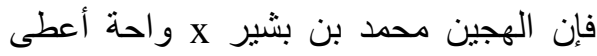

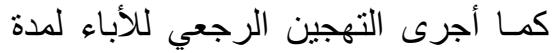

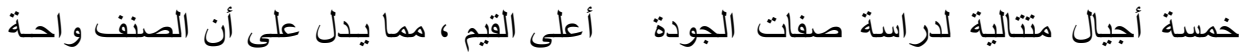

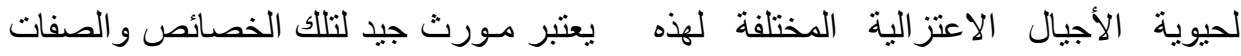

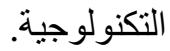

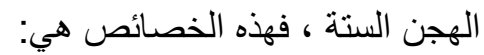

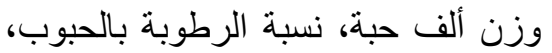

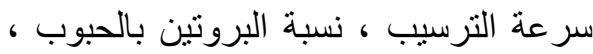
تحكيم: أ.د حامد عبد الرؤوف خليل 